\title{
AN ENEMY OF THE NOVEL
}

\section{Seymour Krim}

For a man who has loved all kinds of prose-writing for as long as he can remember, I find myself in the strange role of villain at the age of 49. Literary villain, I should say. People regard me as an enemy of the novel as a viable art form for this time and place. In order to sleep better tonight, I feel I should explain what brought all of this about and what I really feel.

I was raised on fiction, the US realistic and neo-realistic novel in particular. It gave me my strongest sense of reality and I was eager to live my life, through words, under its banner. But somewhere along the line, in approximately 1955, it seemed to me that the truth of the realistic novel was leaking out of the vessel of the form.

It had originally been created to get closer to experience, especially the unpleasant kind that was covered over by protestant-capitalist advertising; established religion; all the middle-class forces for optimism at the expense of the naked human condition. But I began to notice that the once-bold novelists themselves, the ones I most admired, were disguising home truths in their work instead of getting nearer to the actual.

Using an autobiographical base, they changed their own names and those of their real-life models in order to skirt libel laws; avoid embarassing themselves and their friends; play the good old novel game. But I didn't want literature to be a sport. I wanted it to be a flame, with blessings to Lawrence on that image.

For it to burn, I felt, you had to take chances. You had no choice but to expose yourself; write about the living people you knew; extend the boundaries of permissible reality in a book. It was and is my belief that when any art form becomes "easy," acceptable, formularized, it loses interest and bite. Surely this was happening to the post-realistic novel, I thought, and even more important, it seemed that it was happening to prose literature itself. The media was taking the play away from the written word and if we didn't do something drastic, books themselves were going to end up as harmless objects.

Pretentious as this might sound, it was to re-energise literature as well as to try and strike out into proud new art territory, that made me throw away the mask in my first book, "Views of a Nearsighted Cannoneer."

Instead of using the post-realistic novelist's disguises-changes of name, physical characteristics, a more-or-less coherent plot-I wrote under my own 
scarred signature; named names; gave clinical specimens of blood and sperm; would actually have sewn hunks of soiled underwear and fingernail parings into the book itself if I could have.

My intention, even though the performance was radically far from perfect, was an extension of the realistic novel in the only direction it could logically go -into real, quotidian, actual, scary life itself. No one could read my work-from a formal or aesthetic point of view-and only react to it as successful or unsuccessful art. The reader had to take a stand in relationship to my words.

These words were meant to restore danger to writing, and I don't mean that in a reckless sense. I wanted prose art to carry the weight of action with it; I wanted it to be a wedge into society itself. I had always believed in the highest purposes of literature, at least as I conceived it, and I was goddamned if I'd contribute to its decline or the indifference with which even intelligent people took it by coming out with a book that was only a book.

In America especially, powerful individuals who got things done paid lipservice to "culture" but bought and bullied most conventional artists as if they were so many court entertainers. As a writer in a pragmatic society, I wanted to hit the pragmatists where they lived; bring about tangible change if I could by putting my life and language on the crucial line; show the practical people who run my country that art is a terrible weapon.

This kind of raw assault on the daily reality that surrounds us was necessary to any self-respect I had as a writer. Please keep in mind that I come from a country that flatters the writer as a person of cultural status and flaunts him on television but in the long run regards him as no different from the latest pop star or athlete or Hollywood hustler.

I wanted none of this. Literature always seemed sacred to me, having a special and transcendent purpose, and even though I've soiled that white ideal many times just by the sweat and ooze of living in a competitive show-bizzy kind of world, it was this sense of special mission that seemed to me the No. 1 premise if you were going to call yourself a writer.

My vision of a literature of action, one where the words are hands laid on the reader, and the writer literally reaches out to his partners past the blades of his enemies in an early Christian-type pact, has been called by good critics incredibly romantic. I think I agree, oddly enough. But what's wrong with that? The need that has always driven me into this kind of intimate communication is much more valid for the making of literature in my time than yet another meaningless fiction.

And by saying this, I don't mean to put down fiction for those who get great satisfaction out of either the reading or the writing of it. I speak for myself first and for those like me who find they don't have the inner time or psychic energy to bother with the old-fashioned novel when it seems irrelevant to the spot they're on as highly pressured, self-concerned survivors in a very frightening world.

I want to speak directly to them, move them, actually create through my 
language an "alternate society" with them inside a given piece. My work is meant to be personal, political, critical, journalistic, evangelistic-all at the same time. But to it I would bring everything I have learned from fiction. It is first of all a story, or should be, and it is not about something, but at its best, the thing itself.

I think the best of the so-called New Journalism in the States shares some of these qualities-you can see it in James Agee, Tom Wolfe, Breslin, Mailer, etc. -but I put a twist in it, in attitude, because I also want to use such pieces as a stage on which to act out the scope of my concerns. By that I simply mean that I want to make a deep impact on my American readers in almost every avenue of the mutual life we're all struggling through today.

It's all very well and probably true, as purist critics would say, that such an attitude is egoistic and self-serving. That's a nice, neat tag if you judge writers from the sidewalk. But I'm right in the middle of the shit-heap, as is every emotionally authentic writer in America today, and being what I am and nothing more, I have to fight against the howling noises of the media, the mess, chaos, breakdown of life in my society, and try and fulfill some of the dream that is in me.

So my work gives me a chance to touch all the bases in the form I've devised for myself, and even though I'm aware it is impure by pure literary standards, it is something of a necessity for an American of my time to try and make a multi-faceted grand slam out of a piece of writing in this way.

Theories of literature break down before the facts; and the facts of my culture, my impossible position as a would-be epic writer in a land that by and large doesn't really give a damn for literary values unless you convert them into tangible power, demands that I shape my so-called art in the way I've been speaking of. We have a war on our hands in America even though the enemy changes from day to day and that's why, if I can trust my nose, the bite of gunpowder smells through even our gentlest work, if there is any left.

As for the novel, which was the starting point of all this, what can I say that isn't implied all the way through this statement of aims and needs? If you come from a more settled culture, one that doesn't suffer mental earthquakes every day, perhaps the imaginative coherence of fiction still gives order to people's lives and perhaps it still has a place.

But in the air-conditioned nightmare/daymare that is my home, its immediate wallop has been superseded by film, television, video cassettes coming up, all the electronic genius gadgets that will soon be turning out audio-visual stories that for sheer graphic power will make your Conrads and Flauberts seem like one-horse shays.

In other words, literary artists who would be as supreme as those two devoted maniacs were in their time, must turn elsewhere, in my book, turn where they're needed, and that to me right now is into our disintegrating society where they shall plant the staff of groovy righteousness and justice for all to see and act accordingly. 